\title{
The attractiveness of forests: preferences and perceptions in a mountain community in Italy
}

\author{
I. De Meo, A. Paletto, M.G. Cantiani
}

De Meo I., Paletto A., Cantiani M.G., 2015. The attractiveness of forests: preferences and perceptions in a mountain community in Italy. Ann. For. Res. 58(1): 145-156.

\begin{abstract}
The analysis of the perception and preferences of local communities is a fundamental aspect to increase the social sustainability and to reduce the conflicts between forest users. The knowledge of people's perception of forest resources is important for decision makers, when implementing management strategies and this is particularly relevant in mountainous area, characterized by a strong link between local communities and forest. The paper focuses on the analysis of people's perception and preferences regarding the recreational value of forests. The research has been carried out by means of a case study, the Municipality of Trento, located in the Centre East sector of the Italian Alps. This area was chosen on the grounds of its geographical location and of the historical links that exist between local communities and forest resources. The sample included 1,000 randomly selected families and the method of investigation used was a structured selfreported questionnaire. The data were processed taking into account the relationship between people's perception and the main social characteristics of respondents (gender and age); this allowed statistical differences among groups to be highlighted. Forest attractiveness has been investigated considering: (i) forest accessibility, (ii) forest stand characteristics, (iii) visitor facilities and infrastructures. The results show that people prefer the open mixed forests with an irregular structure and some visitor facilities such as paths and refreshment points. Besides, people like to have facilities in the forests, but at the same time would like these forests to be little frequented by other visitors, in order to have a greater feeling of naturalness. Keywords public preferences, social perception, destination attractiveness, recreation in forest, ecotourism, Italian Alps.
\end{abstract}

Authors. Isabella De Meo (isabella.demeo@entecra.it) - Consiglio per la ricerca in agricoltura e l'analisi dell'economia agraria - Agrobiology and Pedology Centre (ABP), Piazza 'd'Azeglio 30, 50121 Firenze, Italy; Alessandro Paletto - Consiglio per la ricerca in agricoltura e l'analisi dell'economia agraria- Agrobiology and Pedology Centre (ABP), Piazza Monsignor Nicolini 6, 38123 Villazzano diTrento, Italy; Maria Giulia Cantiani - Department of Civil, Environmental, and Mechanical Engineering, University of Trento, via di Mesiano 23, 38123 Trento Italy.

Manuscript received October 27, 2014; revised January 19, 2015; accepted January 29, 2015; online first February 05, 2015. 


\section{Introduction}

Integration of people's preferences and expectations in the decision making process is a relevant aspect of sustainable natural resources management, thereby increasing the social acceptance of the decisions and reducing conflict among users (Beierle 1998, Kangas et al. 2006). Decision makers - managers and policy makers - who are in charge of forest planning and management, can find a valuable support in making their decisions from the empirical findings concerning people's perception of forests (Vierikko \& Kohl 2009, De Meo et al. 2011). In such a way, they can integrate their professional knowledge with information on local people's preferences for forests (Schmithüsen and Wild-Eck 2000).

People's preferences for forests can be defined as the degree to which a person prefers a feature over other features (Sheppard \& Meitner 2005) and they may vary according to attractiveness (scenic beauty) and/or management strategy (Carvalho-Ribeiro \& Lovett 2011). An analysis of people's perceptions and preferences is fundamental in participatory forest planning, as the knowledge local communities have may support decision makers in the management and maintenance of forest resources in an effective way (Lewis \& Sheppard 2005, Šišák 2011). In particular, the decision making process could be influenced by people's perception and preferences concerning the kind of solutions that can be applied and the problems and conflicts to be solved (Sewell 1974).

Moreover, being aware of people's perceptions of the forest management strategies is important for designing and implementing management policies (Cantiani et al. 2001). More and more in recent years, the decision makers need an understanding of the social and psychological factors that influence the people's preferences (Smith et al. 2012). This aspect is particularly significant in mountain areas because these areas are characterized by a strong link between local communities and forest (Tefera et al. 2005; Notaro \& Paletto 2011), and by a particular attention to forest multifunctionality (Grêt-Regamey et al. 2008).

Multifunctional forest planning aims to integrate in decision making the non productive aspects of the forest, just as well as the sociocultural and environmental issues (Vincent \& Binkley 1993, Kangas \& Store 2002). On these basis, the attention to social and ecological values of forests has increased during the last decades (Evans 2001, Hladnik \& Pirnat 2011). The main causes of this change are due to a population redistribution process which has led to a growth of urban areas at the expense of rural areas. The urbanization phenomenon has given rise to an increased distance between people and forests (Nordlund \& Westin 2011). As a result of this fact, ecological and social values have increased in importance, while economic values, such as the traditional timber production, have lost importance. Among the social values, the recreational value of forests is particularly relevant in forests near urban areas (Tahvanainen et al. 2011) and in protected areas (Luo \& Zheng 2008), but also in mountain communities, where there is a strong connection between the urban areas and the surrounding forests.

The recreational value of forest can be investigated using the approach of destination attractiveness. The concept of destination attractiveness and its analysis have been considered in various sectors of research and relating studies, some of which investigate the perceptions that visitors have of destination attractions and resources (Hu \& Ritchie 1993). Destination attractiveness can be defined as "the perceived ability of the destination to deliver individual benefits" (Mayo \& Jarvis 1981). The attributes of the destination enhance this ability and can be classified into two categories (Van Raaij 1986, Laws 1995): innate characteristics (such as natural resources, climate, ecology, etc.) and man-made characteristics (such as transportation facilities, hotels, facilities for sport 
and recreation, etc.).

Considering forest sector and the forest recreational value, several studies investigate the attractiveness of a forest destination (Deng et al. 2002, Kim et al. 2003). The concept that arise is that the attractiveness of a forest destination is related to the individual and unique attributes of the forest itself, including the variety of innate and man-made characteristics and their specific integration which motivate people to visit the forest (Cheng-Fei et al. 2010). Moreover, understanding the diverse attributes of forests that make them attractive to be visited, and investigating visitors' perceptions toward the attractiveness of a forest is an important issue for the actors of the forest sector. In particular, information from these studies are important for implementing recreational and scenic values in forestry policy, forest planning and management. These information contribute to implement the results of the researches finalized to understand the values that individuals attribute to the forest, and represents a starting point to involve the population into the management of the territory (Paletto et al. 2012a).

At the light of these considerations, the aim of the present research is to investigate and evaluate people's preferences for different kind of forests by considering individual preferences. In particular, the research investigates the attractiveness of forests considering various forest attributes such as forest characteristics, forest accessibility, visitor facilities. Since this type of evaluation has recently been introduced into forest management, methods to assess these preferences have not been standardized at today.

The survey method was tested in a case study carried out in the Municipality of Trento (Trentino province). Trentino province is currently reorganizing forest landscape management planning, by shifting from a timber and biomass production to a multifunctional-oriented planning strategy. In particular, the research focused on analysing the possible rela- tionships between the individual preferences and the main territorial variables (tree species composition, canopy openness, horizontal and vertical structure) and social variables (gender and age).

\section{Materials and methods}

\section{Study area}

The municipality of Trento (latitude $46^{\circ} 4^{\prime} 0$ ' $\mathrm{N}$ and longitude $11^{\circ} 7^{\prime} 0$ " $\mathrm{E}$ ) is the main town of the Trentino province, located in the Centre East part of the Italian Alps. It lies in a glacial valley $194 \mathrm{~m}$ a.s.l. and has a territory of 15,792 ha. The population residing in Trento municipality is 114,236 , corresponding to approximately 52,000 families (population density equal to $723 \mathrm{inh} . / \mathrm{km}^{2}$ ). The distribution in age classes is irregular, around $40 \%$ of population is older than 50 years, while only $18.2 \%$ is younger than 18 years. Considering the gender, $47.9 \%$ of the population is female and $52.1 \%$ male.

From the physical-geographical point of view, Trento is deeply linked with the surrounding mountains, since they are easily reachable from the city centre. The closest mountain to the city of Trento (Bondone mountain) can be reached in 30 minutes by car and in 45 minutes by bus $(20 \mathrm{~km})$, while other important mountain areas from the tourism point of view (e.g. Fiemme-Fassa valleys, and Sole valley) can be reached by car in less than 2 hours. Within the municipal territory, forests area is 4,570 ha composed mainly of flowering ash-European hop hornbeam (Fraxinus ornus L. and Ostrya carpinifolia Scop.) forests, European beech (Fagus sylvatica L.) forests, and sparse black and Scots pine (Pinus nigra Arnold and Pinus sylvestris L.) forests. From the administrative point of view, Trento municipality is subdivided into twelve districts, six on the valley floor and six on the adjacent mountainous and hilly areas. The first six districts are more urbanized 
and with an older population, while those of the hill and mountain areas are rural districts characterized by the presence of young families or couples. The forest ownership is divided into communal (public property), collective (common property) and private. The management of public and common forests is made by Azienda Forestale Trento-Sopramonte following the guidelines of the Forest Service of the Province Autonomous of Trento.

\section{Sampling and survey}

The sample was proportionally stratified according to administrative district and included 1,000 randomly selected families.

A mail questionnaire was chosen as the most appropriate research instrument. This kind of instrument allows the collection of a significant amount of information on quantitative and qualitative variables in a short period. These information allow data standardization and comparative analysis. Questionnaires were delivered by mail and a period of six weeks was provided to return them. The questionnaire was equivalent to four pages in length, including an explanatory covering letter that described the case study and the aim of the survey and assured the anonymity of respondents. Three alternatives of delivery systems were given: (1) re-sending by mail service, (2) by prior arrangement, direct delivery to collection centres such as libraries and other public offices, (3) collection by operators (only by appointment). These procedures, currently used by mail surveys, were chosen in order to reduce the percentage of missing answers.

\section{Questionnaire}

The self-reported questionnaire is designed to explore a range of issues relating to monitoring and identifying relationship between people and forests such as: the perception of forest management and landscape changes, the bond of the population with the mountain, the pref- erences given to forest features and functions and, finally, knowledge, feelings and emotions of people toward forests.

The questionnaire contains 56 questions arranged into four sections: "respondent personal details", "forest perception", "community and forest", "knowledge and information about forest". The subdivision into sections is important as it prevents from getting tired/bored, and it is generally suggested in questionnaires (Nielsen et al. 2007). The questionnaire was pre-tested and various revisions were then carried out before the definitive version, in which the language used is simple and uncomplicated and questions stimulate the expression of opinions, expectations and feelings. People were asked to consider all the forests in the entire province and to indicate in the questionnaire which forest areas they were referring to.

The paper focuses on the section of the questionnaire which explores "forest perception" and, in particular, on the questions that investigate attractiveness of forests. The forest attributes under consideration included (Table 1): forest accessibility, forest characteristics, visitor facilities. Accessibility and forest characteristics are innate features of forests, influenced by man through management practices, whereas visitor facilities are man-made characteristics (Cheng-Fei et al. 2010).

Concerning forest accessibility, people's preferences for forest location and attendance are considered. These two characteristics are closely related to the forest trails network, and to the distance from urban areas. Forest accessibility - analyzed considering jointly forest location and attendance - shows people's preferences towards four macro-types of forest as illustrated in Fig. 1. Preferences can be positioned along a continuous between urban forests (people who prefer forests much frequented by tourists, accessible by car and near to the urban areas) and remote forests (people who prefer forests not frequented by tourists, far from trails and urban areas).

Preferences for forest characteristics are 
Table 1 Questions investigating attractiveness of forests

\begin{tabular}{|c|c|c|c|}
\hline \multicolumn{2}{|c|}{ Issue } & \multirow{2}{*}{$\begin{array}{l}\text { Question } \\
\text { Which kind of forest do you } \\
\text { prefer? }\end{array}$} & \multirow{2}{*}{$\begin{array}{l}\text { Options } \\
\text { Forest areas accessible by car } \\
\text { Forest areas near to trails } \\
\text { Forest areas far from trails }\end{array}$} \\
\hline$\stackrel{2}{\Rightarrow}$ & Location & & \\
\hline & Attendance & $\begin{array}{l}\text { Which kind of forest do you } \\
\text { prefer? }\end{array}$ & $\begin{array}{l}\text { Forest much frequented by visitors } \\
\text { Forest little frequented by visitors } \\
\text { Forest not frequented by visitors }\end{array}$ \\
\hline \multirow{3}{*}{ 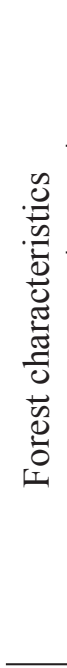 } & $\begin{array}{l}\text { Tree species } \\
\text { composition }\end{array}$ & $\begin{array}{l}\text { Which kind of species } \\
\text { composition do you prefer in } \\
\text { a forest? }\end{array}$ & $\begin{array}{l}\text { Broadleaf forest } \\
\text { Evergreen forest } \\
\text { Mixed forest }\end{array}$ \\
\hline & Canopy openness & $\begin{array}{l}\text { Do you prefer open or close } \\
\text { forests? }\end{array}$ & $\begin{array}{l}\text { Open forest } \\
\text { Closed forest }\end{array}$ \\
\hline & Stand structure & $\begin{array}{l}\text { Which kind of forest structure } \\
\text { do you prefer? }\end{array}$ & $\begin{array}{l}\text { Regular, with uniform distribution of trees } \\
\text { and low differentiation in heights and } \\
\text { diameters } \\
\text { Irregular, with random distribution of trees } \\
\text { and high differentiation in heights and } \\
\text { diameters } \\
\text { Irregular, but also with a presence of } \\
\text { old trees, standing dead trees and lying } \\
\text { deadwood }\end{array}$ \\
\hline 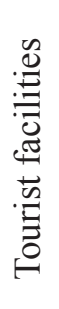 & Facilities/infrastructures & $\begin{array}{l}\text { In your opinion, what is } \\
\text { important to find in a forest? }\end{array}$ & $\begin{array}{l}\text { Paths } \\
\text { Picnic benches and tables, and barbecues } \\
\text { Fitness trails and other sports equipment } \\
\text { Panoramic views } \\
\text { Refreshment points } \\
\text { Parking areas } \\
\text { Places of historical and religious interest }\end{array}$ \\
\hline
\end{tabular}

studied in investigating attractiveness of forests with regard to changes in three macrocharacteristics: stand structure, canopy openness and tree species composition. These three macro-characteristics were chosen on the basis of simplicity in perceiving the differences from the aesthetic point of view. Stand structure is evaluated considering the diversity of trees position in the space and the diversity of trees dimensions in height and diameter (Pommerening 2002). The combination of these three aspects has given rise to three stand structure classes: (i) forest stands with a regular distribution of the trees in the space and a low differences in the diameter and height distribution; (ii) forest stands with a clumped and random distribution of the trees in the space and a high differences in the diameter and height distribution; (iii) forest stands with a clumped and random distribution of the trees in the space and scattered presence of old trees, standing dead trees and lying deadwood. According to FRA2000 the canopy openness is subdivided in two classes (FAO, 2001): (i) open forests when the canopy cover is less than $40 \%$, (ii) closed forests when the canopy cover is more than $40 \%$. Finally, tree species composition is evaluated taking into account the percentage distribution between evergreen and deciduous species, pure forests are considered when the percentage of the species most poor is less than $20 \%$. 


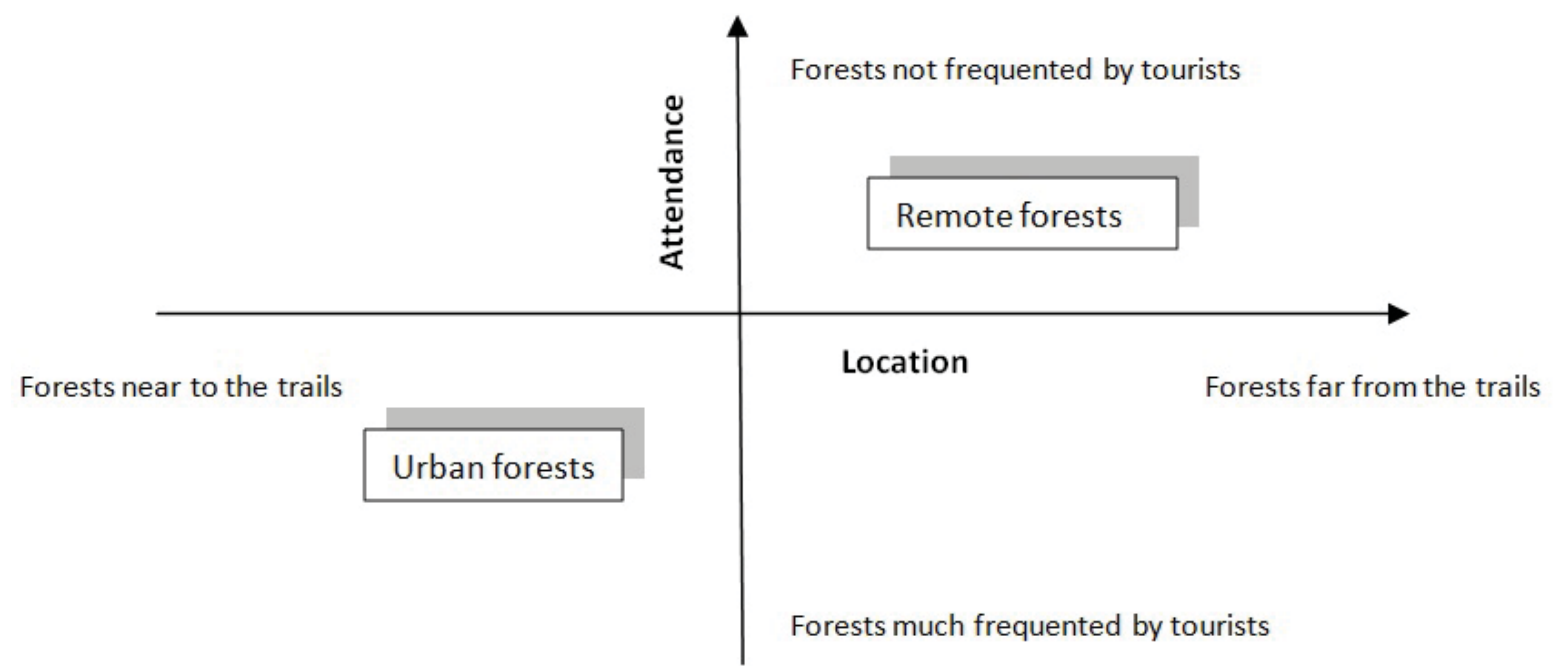

Figure 1 Classification of forests considering the location and attendance

Visitor facilities are analyzed considering the people's perception and preferences on the main works and infrastructures for enhancing the tourist-recreational function of forest such as paths, picnic areas, fitness trails, panoramic views, refreshment points, parking areas and places of historical and religious interest.

The attractiveness of visitor facilities in forests is investigated asking the respondents to assess the level of importance assigned to the different kind of facilities and infrastructures using a 10-point Likert scale (from $0=$ lowest level of importance to $10=$ highest level of importance).

The questions related to the accessibility and forest characteristics are in closed-form with a single choice.

All statistical analyses were carried out using XLStat 2012. The data collected are analyzed statistically with special regards to gender and age.

\section{Results}

The response rate was $34.6 \%$, with 345 questionnaires collected and processed. Of the respondents, 66\% were men (229) and 34\% were women (116).

Four age classes were considered (18-35 years old; $36-55$; 56-75 and more than 75 years old). The age class 36-55 represented 41\% of the sample. Furthermore, the very elderly group (over 75) were represented by almost $11 \%$ of the population sample (Fig. 2).

Results concerning forests' accessibility showed that around $50 \%$ of the respondents prefer the forests near to the trails, while $36.2 \%$ of the respondents prefer those far from the trails. Considering the attendance, respondents have a preference for forests with few tourists $(77.2 \%)$ or even without tourists $(16.7 \%)$. The joint analysis of these two questions shows that only $5 \%$ of the respondents appreciate the urban forests, while $59.1 \%$ prefer forests near trails but with few tourists and 35.1\% appreciates remote forests (Fig. 3). Considering the gender, female preference for forests near to trails but with few tourists is higher than that of males, while the remote forests are appreciated especially by males.

As far as forest characteristics are concerned, results relating to tree species composition highlight that people living in Trento prefer mixed forests $(65.6 \%)$ to evergreen $(28.2 \%)$, and broadleaf forests $(6.2 \%)$. Considering the gender of respondents it is possible to observe a predominance of female preference $(72.6 \%)$ over male preference $(62.7 \%)$ insofar as mixed forests are concerned. Using the Chi-square test, no statistically significant differences were found. Moreover, the results show that 


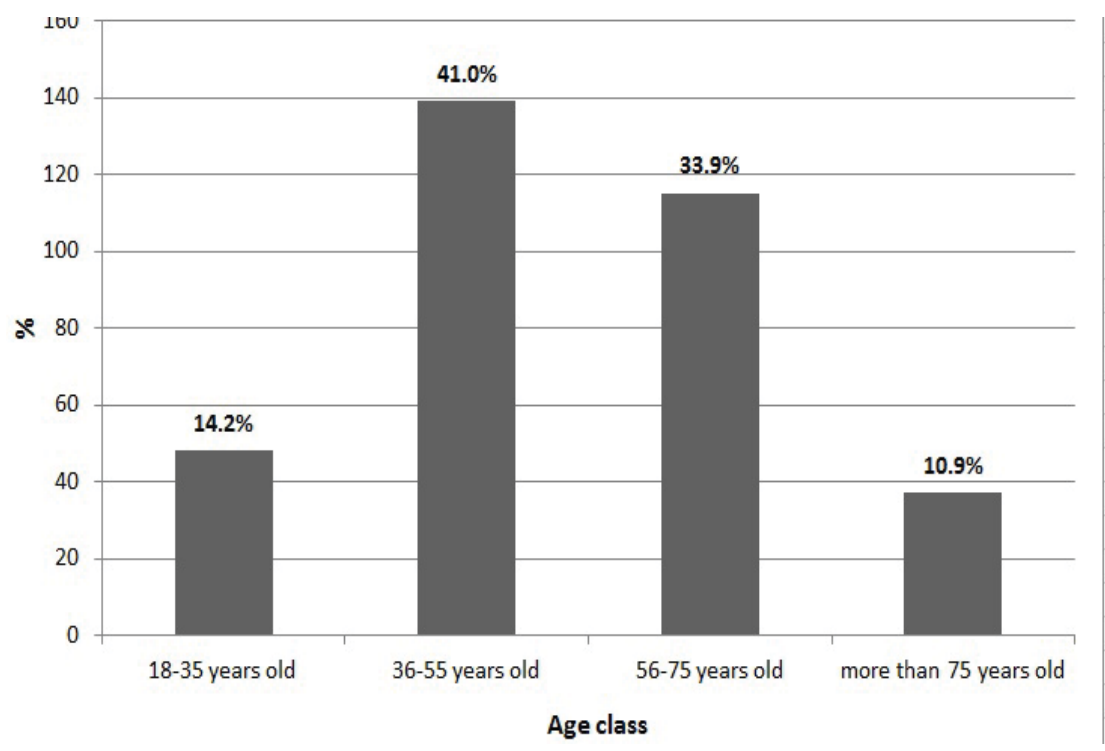

Figure 2 Distribution of the sample per age classes

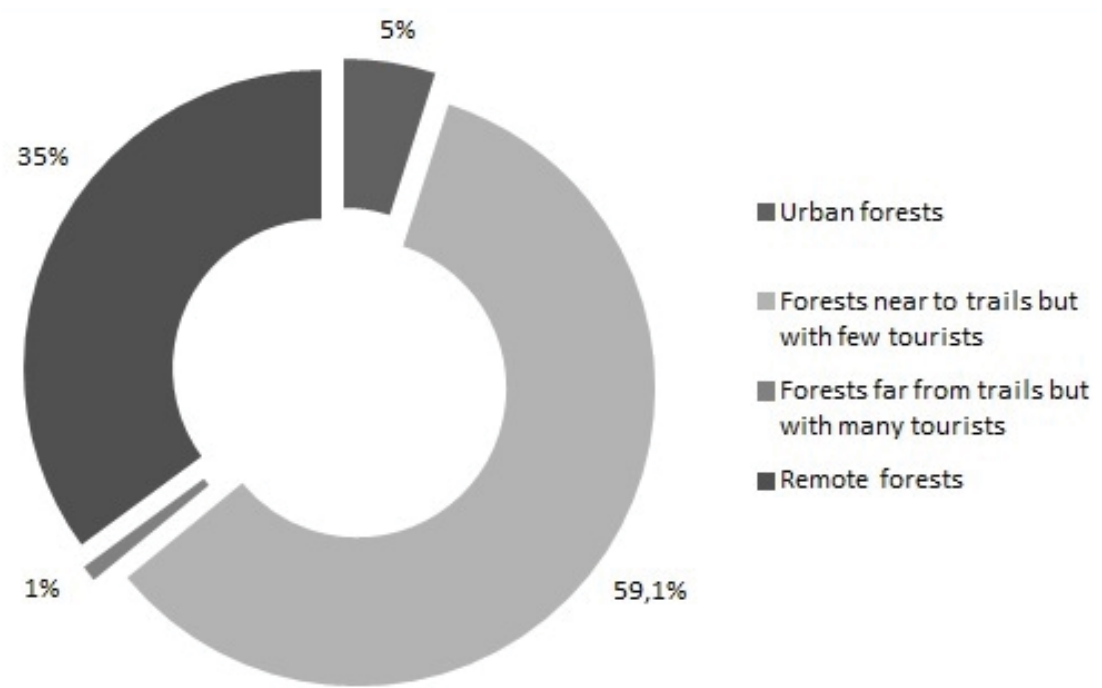

Figure 3 Distribution of the respondents' preferences in consideration of location and attendance

young people have a higher preference for broadleaf forests $(14.6 \%)$, while elderly people prefer the evergreen forests $(43.2 \%)$. In Trentino province the evergreen forests (i.e. Norway spruce and Scots pine forests) are traditionally considered the "typical" forest types, consequently it is possible that the elderly assigned a high value to these forests for cultural and not for aesthetic reasons. On the other side the young people, less linked to the traditional and cultural context of the territory, assigned a value based only on aesthetic considerations. A significant difference among the age groups $\left(\chi^{2}\right.$ test: observed value $=19.934$, critical value $=12.592, P=0.003$, alfa $=0.05$ ) was observed.

With regard to canopy openness, the results show that $82.4 \%$ of respondents prefer open forests, while only $17.6 \%$ prefer closed forests. Taking into consideration the gender, female preference for open forests is higher than that of males $\left(\chi^{2}\right.$ test: value observed $=3.909$, criti- 
cal value $=3.841, P=0.048$, alfa 0.05$)$.

The forest structure preferred by people living in Trento is the irregular (both horizontal and vertical) structure (86.6\%). The highest preference is accorded to forests with a random distribution of the trees in the space and a high diameter differentiation of trees (58.6\%) and, secondly, to irregular forests, but also with presence of old trees, standing dead trees and lying deadwood (28.0\%). A significant difference between males and females was observed, with females more oriented towards the typical uneven-aged forests $\left(\chi^{2}\right.$ test: observed value $=$ 6.219 , critical value $=5.991, P=0.045$, alfa $=$ $0.05)$.

Concerning man-made characteristics of destination attractiveness of a forest, Table 2 shows the attractiveness of visitor facilities. For respondents of Trento municipality, paths and refreshment points (with a score of 7.8 out of 10) are considered the most important visitor facilities. Also the presence of parking areas is an important facility, with a score of 7.0 out of 10 . On the other side, picnic benches and tables, and fitness trails are considered of lesser importance. It is interesting to highlight that the female assign higher values to the presence of the paths and parking close to the forests. The male assign higher values only two facilities: panoramic views and refreshment points. The significance of differences between gender was assessed by the nonparametric Mann-Whitney test that showed significant statistically differences only for the paths $(\mathrm{U}=10333.50$, attended value $=12765.00$, $p$-value $=0.003$, variance $=663133.4$, alfa $=$ $0.01)$.

Considering the age, the most interesting result is that the elderly assign a higher value to almost all the facilities. The non parametric Kruskal-Wallis test was applied to determine the statistical significance of differences based on age. It showed a significant difference with regard to the following facilities: paths ( $\mathrm{K}$ observed value $=14.159, \mathrm{~K}$ critical value $=$ $11.345, p$-value $=0.003$, alfa $=0.01)$ and historical and religious places $(\mathrm{K}$ observed value $=11.388, \mathrm{~K}$ critical value $=11.345, p$-value $=$ 0.010 , alfa $=0.01$ ).

Figure 4 shows a summary of information concerning the preferences of the inhabitants of Trento municipality on the attractiveness of forests.

\section{Discussion and conclusions}

This research has provided useful information for the new multifunctional approach to forest planning. Information regarding the perception expressed by the population can be compared with the data obtained from surveys on the for-

Table 2 Mean values assigned to the main tourist facilities by the respondents (10-point Likert scale - from $0=$ lowest level of importance to $10=$ highest level of importance)

\begin{tabular}{|c|c|c|c|c|c|c|c|}
\hline Characteristics of respondents (n) & Paths & $\begin{array}{l}\text { Picnic } \\
\text { areas }\end{array}$ & $\begin{array}{l}\text { Fitness } \\
\text { trails }\end{array}$ & $\begin{array}{l}\text { Panoramic } \\
\text { views }\end{array}$ & $\begin{array}{l}\text { Refreshment } \\
\text { points }\end{array}$ & $\begin{array}{l}\text { Parking } \\
\text { areas }\end{array}$ & $\begin{array}{l}\text { Historical } \\
\text { and } \\
\text { religious } \\
\text { places }\end{array}$ \\
\hline \multicolumn{8}{|l|}{ Gender } \\
\hline Male (n = 229) & 7.55 & 3.63 & 3.69 & 4.69 & 7.87 & 6.89 & 5.30 \\
\hline Female $(\mathrm{n}=116)$ & 8.40 & 3.85 & 3.97 & 4.68 & 7.81 & 7.27 & 5.34 \\
\hline \multicolumn{8}{|l|}{ Age } \\
\hline $18-35$ years old $(n=48)$ & 7.00 & 3.29 & 3.27 & 3.73 & 7.67 & 6.79 & 4.17 \\
\hline $36-55$ years old $(n=140)$ & 7.72 & 3.57 & 3.66 & 4.71 & 8.04 & 7.35 & 5.17 \\
\hline $56-75$ years old $(n=119)$ & 8.23 & 3.61 & 4.11 & 4.74 & 7.68 & 6.79 & 5.82 \\
\hline More than 75 years old $(n=38)$ & 8.28 & 5.20 & 4.09 & 5.94 & 8.00 & 6.73 & 5.82 \\
\hline Total $(\mathrm{n}=345)$ & 7.84 & 3.70 & 3.78 & 4.69 & 7.85 & 7.02 & 5.32 \\
\hline
\end{tabular}




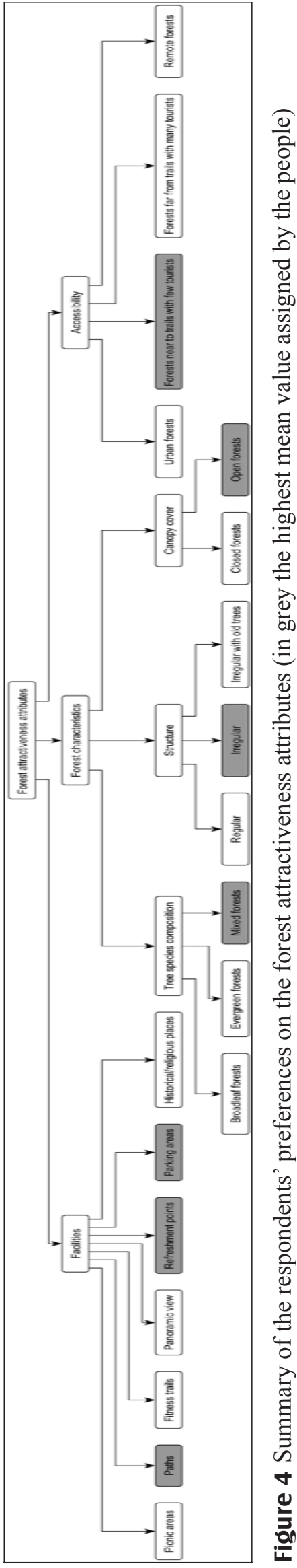

est stands. In this way, the results may support management options that take in consideration people's vision in the decision making process. In particular, these information could have a great importance in the management of public and common forests in Trentino province.

The response rate of the present research is slightly higher than those reported in literature. Indeed, other research carried out in Italy has reported a response rate between $20 \%$ and $30 \%$ (Montini 2001).

Concerning forest characteristics the results showed that respondents assigned the lowest preference to the broadleaf forests. This may be due to the fact that in the areas surrounding the Municipality of Trento the broadleaf forests are coppices of low aesthetic value (alder and downy oak forests), or young European beech forests derived from the conversion, since the 1960s, of previous beech coppices.

The responses received to the questions relating canopy openness and structure showed that irregular and open forests with a high degree of natural diversity seem to be the kind of forest more attractive for the majority of respondents. These findings confirm that the naturalness of a forest is important in determining tourism attractiveness and that a natural environment - through, for example, the sighting of a landscape or of a particular species of plant or of animal - provides "moment of magic" and "wow factor" to the visitors (Stern et al. 1993).

This idea of forest fits quite well into the type of ecosystem that the Forest Service of the Province Autonomous of Trento has been designing over the last fifty years (forest guidelines), where the ecological conditions made it possible. Such ecosystem is made up of mixed and uneven-aged forests, ensuring the best possible protection for the soil in mountainous areas and a good maintenance of fertility and conservation of biodiversity.

From the point of view of the visitor facilities, people look for a good network of paths, and for the presence of refreshment points. 
These results and the fact that recreation facilities such as picnic benches and tables are considered of lower importance, are in accordance with Martin (2008), who affirms that if the main motivations for visiting forests are to be close to nature and to experience quiet and contemplation, recreation provisions are not essential.

These results actually perfectly represent spirit and attitudes towards forests of people belonging to an alpine community, such as the municipality of Trento. In this area we deal with people who are familiar with forests and used to mountain ecosystems frequentation: in the past mainly for the traditional economic activities (forestry and grazing), today for recreational purposes. The recreational demand by society has changed over the past decades: some outdoor activities - such as walking, picnicking, landscape viewing, mushrooms and berries picking - have become an increasingly important (Paletto et al. 2012b). The local decision makers need to consider these aspects in order to meet this social demand. In suitable forest areas, the implementation of forest management practices aimed at enhancing the landscape and the non-wood forest products (NWFP) can be very important. Furthermore the forests of this area are important not only for the local population but also for people coming from all over the country: nowadays tourism is in fact a very important element of the economy of the province. For this reason people's preference towards destination attractiveness of forests must be carefully considered, particularly when managing forests with a high recreational use.

In conclusion, we can assert that the respondents like the feeling of being in a forest with a high naturalness but without sacrificing the basic visitor facilities such as parking areas and paths. In other words, people like to have facilities in the forests, but at the same time would like these forests to be little frequented by other visitors, in order to have a greater feeling of naturalness. This phenomenon is typi- cal of post-modern societies (Inglehart 1997), with a high urbanization and a high level of education just as the case study. In these societies people look for easy ways to be in contact with a "wild" nature, without sacrificing any comfort. For this reason in these societies the environmental and social forest functions (i.e. biodiversity conservation and recreation in forest) are currently regarded as more important than the economic functions of forests (i.e. timber and fuelwood production) (Tarrant et al. 2003).

Studies in perception therefore may prove to be very useful in order to support managers and decision makers in articulating forest management goals and strategies and in designing and implementing policies at local level. It is of course obvious that the meanings that forests and forest management practices may hold for people are deeply rooted in the local context, and that the results of studies based on a sample of respondents cannot be generalized.

\section{Acknowledgments}

The research was carried out within the $\mathrm{Na}$ tional Project Ri.Selv.Italia (Subproject 4.2 - Forest Planning) at the Ecology Laboratory of the University of Trento: funding for this project was provided by Ministry of Agriculture and Forests. The authors contributed to this paper in equal parts.

\section{References}

Beierle T.C., 1998. Public participation in environmental decisions: An evaluation framework using social goals. Discussion Paper 99-06, Washington DC: Resources for the future.

Cantiani M.G., Bettelini D., Mariotta S., 2001. Participatory forest planning: a chance of communication between forest service and local communities. In: Proceedings of the International Conference FAO/ECE/ILO. Forestry meets the Public. Ruttihubelbad, pp. 249-263.

Carvalho-Ribeiro S.M., Lovett A., 2011. Is an attractive forest also considered well managed? Public prefer- 
ences for forest cover and stand structure across a rural/ urban gradient in northern Portugal. Forest Policy and Economics 13: 46-54.

Cheng-Fei L., Hsun-I H., Huery-Ren Y., 2010. Developing an evaluation model for destination attractiveness: sustainable forest recreation tourism in Taiwan. Journal of Sustainable Tourism 18(6): 811-828, 2010. DOI: 10.1080/09669581003690478.

De Meo I., Cantiani M. G., Ferretti F., Paletto A., 2011. Stakeholders' Perception as Support for Forest Landscape Planning. International Journal of Ecology 1: 1-8. DOI: $10.1155 / 2011 / 685708$.

Deng J., King B., Bauer T., 2002. Evaluating natural attractions for tourism. Annals of Tourism Research 29(2): 422-438. DOI: 10.1016/S0160-7383(01)00068-8.

Evans J., 2001. The Forests Handbook: Applying Forest Science for Sustainable Management. Oxford: Blackwell Science Ltd.

FAO, 2001. Global Forest Resources Assessment 2000. Main Report. Rome: FAO Forestry Paper 140.

Grêt-Regamey A., Walz A., Bebi P. 2008. Valuing Ecosystem Services for Sustainable Landscape Planning in Alpine Regions. Mountain Research and Development 28: 156-165. DOI: 10.1659/mrd.0951.

Hladnik D., Pirnat J., 2011. Urban forestry - linking naturalness and amenity: the case of Ljubljana, Slovenia. Urban Forest \& Urban Greening 10(2): 105-112. DOI: 10.1016/ j.ufug.2011.02.002.

Hu Y., Ritchie J.R.B., 1993. Measuring Destination Attractiveness: A Contextual Approach. Journal of Travel Research 32(2): 25-34. DOI: 10.1177/0047287593032 00204.

Kangas A., Laukkanen S., Kangas J. 2006. Social choice theory and its applications in sustainable forest management - a review. Forest Policy and Economics 9: 7792.

Kangas J, Store R., 2002. Socioecological Landscape Planning: An Approach to Multi-Functional Forest Management. Silva Fennica 36(4): 867-871. DOI: 10.14214/sf.527.

Kim S.S., Lee C.K., Klenosky D.B., 2003. The influence of push and pull factors at Korean national parks. Tourism Management 24: 169-180. DOI: 10.1016/S02615177(02)00059-6.

Inglehart R., 1997. Modernization and Postmodernization: Cultural, Economic, and Political Change in 43 Societies. Princeton: Princeton University Press.

Laws E., 1995. Tourism destination management: Issues, analysis, and policies. New York: Routledge.

Lewis J.L., Sheppard S.R.J., 2005. Ancient Values, New Challenges: Indigenous Spiritual Perceptions of Landscapes and Forest Management. Society and Natural Resources 18: 907-920. DOI: 10.1080/089419205002 05533.

Luo J., Zheng J., 2008. Ecotourism in nature reserves in China: current situation, problems and solutions. Forest Scence and Practice 10(2): 130-133.

Martin S., 2008. Developing woodlands for tourism: Con- cepts, connections and challenges. Journal of Sustainable Tourism 16(4): 386-407. DOI: 10.1080/096695808 02154181 .

Mayo E.J., Jarvis L.P., 1981. The psychology of leisure travel: effective marketing and selling of travel service. Boston: CBI Publishing.

Montini A., 2001. L'uso del questionario nella valutazione contingente [The use of questionnaire in the contingent valuation]. Torino, Italy: Fabio Nuti, Giappichelli Editore.

Nielsen A.B., Olsenb S.B., Lundhede T., 2007. An economic valuation of the recreational benefits associated with nature-based forest management practices. Landscape Urban Plan 80: 63-71. DOI: 10.1016/j.landurbp lan.2006.06.003.

Nordlund A., Westin K., 2011. Forest values and forest management attitudes among private forest owners in Sweden. Forests 2: 30-50. DOI: 10.3390/f2010030.

Notaro S., Paletto A., 2011. Links between Mountain Communities and Environmental Services in the Italian Alps. Sociologia Ruralis 5: 137-157. DOI: 10.1111/ j.1467-9523.2011.00532.x.

Paletto A., Maino F., De Meo I., Ferretti F., 2012a. Perception of forest values in the alpine community of Trentino region (Italy). Journal of Environmental Management 51(2): 414-422. DOI: 10.1007/ s00267-012-9974-7.

Paletto A., Ferretti F., Cantiani P., De Meo I., 2012b. Multifunctional approach in forest landscape management planning: an application in Southern Italy. Forest Systems 21(1): 68-80. DOI: 10.5424/fs/2112211-11066.

Pommerening A., 2002. Approaches to quantifying forest structures. Forestry 75: 305-324. DOI: 10.1093/forestry/75.3.305.

Schmithüsen F., Wild-Eck S., 2000. Uses and perceptions of forests by people living in urban areas - findings from selected empirical studies. European Journal of Forest Research 119: 395-408.

Sheppard S.R.J., Meitner M., 2005. Using multi-criteria analysis and visualisation for sustainable forest management planning with stakeholder groups. Forest Ecology and Management 207: 171-187. DOI: 10.1016/ j.foreco.2004.10.032.

Sewell W. R. D. 1974. Perceptions, attitudes and public participation in countryside management in Scotland. Journal of Environmental Management 2: 235-257.

Smith J.W. , Siderelis C., Moore R.L., Anderson D.H. 2012. The effects of place meanings and social capital on desired forest management outcomes: A stated preference experiment. Landscape and Urban Planning 106: 207-218. DOI: 10.1016/j.landurbplan.2012.03.009.

Stern P.C., Dietz T., Kalof L., 1993. Value orientations, gender, and environmental concern. Environment and Behavior 25(5): 322-348. DOI: 10.1177/00139165932 55002.

Šišák L., 2011. Forest visitors' opinions on the importance of forest operations, forest functions and sources of their financing. Journal of Forest Science 57: 266-270.

Tahvanainen L., Tyrvainen L., Ihalainen M., Vuorela N., 
Kolehmainen O., 2011. Forest management and public perceptions - visual versus verbal information. Landscape and Urban Planning 53: 53-70. DOI: 10.1016/ S0169-2046(00)00137-7.

Tarrant M.A., Cordell H.K., Green G.T., 2003. PVF. A scale to measure public values of forests. Journal of Forestry 9:24-30.

Tefera M., Demel T., Hultén H., Yemshaw Y., 2005. The Role of Communities in Closed Area Management in Ethiopia. Mountain Research and Development 25(1): 44-50. DOI: 10.1659/0276-4741(2005)025 [0044: TROCIC]2.0.CO;2.
Van Raaij W.F., 1986. Consumer research on tourism: Mental and behavioral constructs. Annals of Tourism Research 13(1): 1-9. DOI: 10.1016/01607383(86)90054-X.

Vierikko K., Kohl J., 2009. Improving the ecologically sustainable forest management behaviour - qualitative frame analysis for argumentation. Annals Forest Research 52: 169-1

Vincent J.R., Binkley C.S., 1993. Efficient Multiple Use Forestry may require Land-Use specialization. Land Economy 69(4): 370-376. DOI: 10.2307/3146454. 